\title{
Endangered languages in public outreach: Lessons for linguists
}

\author{
Radostaw Wójtowicz \\ INSTITUTE OF LINGUISTICS, ADAM MICKIEWICZ UNIVERSITY \\ AL. NIEPODLEGŁOŚCI 4, 61-874 POZNAŃ \\ rwojtowi@amu.edu.pl
}

\begin{abstract}
Linguists who collaborate with communities of speakers of endangered languages emphasize that it is often very practical matters such as the availability of resources or the political conditions in which they conduct fieldwork that influence their work the most. This article shows that linguists acting for the sake of endangered languages in a totally different environment, i.e. at European schools with students and teachers who usually are not familiar with the topic of language endangerment, may face similar challenges. I report on the results of a public outreach project aimed at raising awareness of language endangerment among secondary school communities in four European countries, and focus on Poland in particular. Three parallels with linguistic fieldwork are drawn in this article which are to illustrate that similarly to language documentation and revitalization projects, in public outreach enterprises the goals and views of external linguists may be radically different from those of the non-linguist parties involved. Mundane as they may seem, issues such as teachers' working conditions need to be understood and properly addressed by linguists who wish to effectively bring their message about endangered languages across to the general public.
\end{abstract}

\section{Introduction}

That languages are dying out is an alarming issue and a question which makes an increasing number of linguists engage in language documentation and revitalization projects. ${ }^{1}$ But although the academic community

1 This work was supported by the $7^{\text {th }}$ Framework Programme of the European Commission under grant agreement no. 284415. The creation of the educational product described in the present article involved close collaboration of all linguists based in the Polish branch of the Innovative Networking in Infrastructure for Endangered Languages 
has been vividly interested in endangered languages for several decades already, the importance of bringing the message about dying languages across to the general populace still receives relatively little attention from linguists. Consequently, the observation made by Nettle \& Romaine (2000: 14) that "few people know or care" about the plight of many of the world's lesser-used languages is as valid today as it was at the time when their famous book was published. Crystal $(2003,2011)$ makes a particularly loud call for crossing what he terms 'the great divide' in knowledge and awareness of linguistic diversity and language endangerment between language scholars and non-linguists. Alongside the Internet, the arts and the media, Crystal lists the school curricula as a possible scene of interaction with non-linguists on which the divide could be bridged. This paper reports on efforts recently undertaken in the scope of the Innovative Networking in Infrastructure for Endangered Languages project (INNET) in four European countries: Germany, Hungary, the Netherlands and Poland, an enterprise aimed at testing that scene in local settings at the secondary school level.

I will not, however, discuss how the public outreach project behind this paper has contributed to raising awareness of language diversity and endangerment among secondary school communities. Instead, I will concentrate on very practical issues which emerged in the course of the project. Especially in Poland, visits paid to secondary schools uncovered problems stemming from how the school system is organized which turned out to be of no less relevance for the prospects of the topic of language endangerment staying in schools for longer than the language attitudes of the people interviewed. My main focus in this paper will be on the role of external linguists in enterprises of such kind. Similarly to documentary linguists and language revitalizers from outside the communities of speakers of endangered languages, linguists who enter schools with a task of raising awareness of language endangerment among ordinary people may have goals and motivations which stand at contradiction with those of the nonlinguists with whom they collaborate.

Good cooperation between linguists and speech communities is an asset in language documentation (Himmelmann 1998, Gippert et al. 2006)

Project (INNET): Nicole Nau, Katarzyna Klessa, Tomasz Wicherkiewicz, Michael Hornsby, Maciej Karpiński, Katarzyna Linda and myself (Adam Mickiewicz University in Poznań, Poland), but it was my own idea to present the issues that we had encountered in the process as parallels to other kinds of work for endangered languages. The semistructured interview used during the assessment phase was designed by Michael Hornsby. My particular thanks go to Nicole Nau and Tomasz Wicherkiewicz who provided helpful comments on earlier drafts of this paper. I cannot overemphasize the invaluable help and advice on the part of the teachers and the students who contributed to the development of the product. I would also like to acknowledge my colleagues from the remaining three branches of INNET: Dagmar J ung (University of Cologne, Germany), Marianne Bakró-Nagy, Zsuzsa Duray, Beatrix Oszkó, Mária Sipos, Sándor Szeverényi, Zsuzsa Várnai (Research Institute for Linguistics of the Hungarian Academy of Sciences, Budapest, Hungary) and Paul Trilsbeek (Max Planck Institute for Psycholinguistics, Nijmegen, the Netherlands). 
and indeed one of the prerequisites of successful language revitalization (Grenoble \& Whaley 2006). Obviously, the creation and implementation of school materials which familiarize outsiders to the world of linguistic diversity with the work of people who help maintain it likewise requires smooth collaboration with the future users of such materials. I will discuss this collaboration terms of encounters between language professionals on the one hand and different groups of non-linguists on the other. In fieldwork conditions, such a binary division is artificial as there are linguists within many speech communities who contribute to revitalization programmes and in general, successful language revitalization is one driven by the community and not by outsiders (Grenoble 2009). In this respect, and in many other senses, the enterprise described here differs considerably from the work of documentary linguists. In the case of the INNET project, it was the initiative of linguists and not of students or teachers to make language endangerment a topic of school activities. Nevertheless, or precisely because of this, questions of responsibility that linguists bear to non-linguists turned out to be as crucial for the success of the enterprise as they generally are wherever linguists come together with communities of speakers of endangered languages. In describing issues which arose during the creation of an educational product about endangered languages developed as one of the main results of INNET, I will draw parallels with language documentation and revitalization in terms of three problems commonly discussed by linguists experienced in linguistic fieldwork: the question of divergent goals, of expertise necessary for the elaboration and use of teaching materials, and of the uniqueness of each local situation.

I will discuss these three parallels one by one in sections 3, 4 and 5 . Similarities to aspects of linguistic fieldwork were identified during different stages of the present project. For this reason, I will first describe the consecutive phases of the project in section 2. My particular focus in sections 2, 3 and 4 is on Poland which was the main scene for the development and testing of the materials, whereas section 5 is dedicated to the differences between the four participating countries. Section 6 concludes the article.

\section{Product development}

The context in which endangered languages are present in education most commonly involves the teaching of endangered languages to members of the communities who use them (e.g. Slaughter 1997, Hornberger \& King 2001, Admiraal 2012, Amery \& Buckskin 2012). In Europe with its 284 living languages (Lewis, Simons \& Fennig 2014), i.e. on the world's poorest continent in terms of linguistic diversity, it is particularly important to also teach about endangered languages to people who often have neither the access to them nor the knowledge they exist. All the more so because the language attitudes held by the powerful Western societies are found among the factors which make the world's lesser-used languages disappear (cf. Dorian 1998). Fortunately, Europe also has a wealth of resources to educate 
itself on language endangerment, on the reasons behind the phenomenon and on its consequences for the humankind. The enterprise described here benefitted from these resources. In the scope of the INNET project, an educational product revolving around aspects of language endangerment was created between December 2011 and September 2014. 'The product', as it shall be referred to henceforward, is a multimedia-supported school information package available at http://languagesindanger.eu. It was developed at Adam Mickiewicz University in Poznań, Poland (AMU), in collaboration with three other European research institutions, teachers and students at European secondary schools, as well as numerous linguists working on the world's endangered languages.

The product is targeted at 16-17-year-olds and their teachers from the four partner countries of the project: Germany, Hungary, the Netherlands and Poland. The main responsibility for product development lay with linguists based in the Polish branch of the project (AMU), meaning that most of the underlying investigation was conducted in the Polish setting and the product was subsequently localized for the educational markets of the remaining three countries. The first phase of product development involved an examination of the awareness of linguistic endangerment and diversity among school communities, as well as searching for possibilities within the already existing school curricula to introduce such topics to secondary education. Upon completion of the assessment stage it was possible to establish the general shape of the product. The next phase was the creation of the material, followed by its testing in schools. Subsequently, the final version was prepared based on the results of the testing.

\subsection{Assessing awareness}

From November 2011 to J anuary 2012, a team of AMU linguists visited seven schools across Poland to talk about endangered languages with students and teachers. Of these, six were regular general secondary schools and the remaining one a junior secondary school, chosen for the purposes of a pilot study. Overall, the team met 13 groups of approximately 25 students, and 22 teachers. Four of the schools are located in major Polish cities (Poznań, Lublin and Opole), one in a town of 175,000 people (BielskoBiała) and the remaining two in the small towns of Wronki and Wilamowice. The junior secondary school is based in Wilamowice, hometown to the endangered Wilamowicean language, whereas the region of Opole is inhabited by the German minority, which makes it a site of a natural contact of Poles and a community of speakers of a language other than Polish. The remaining schools are located in places where regular access to the other languages of Poland is limited and where at best, young people's day-to-day Polish displays phonetic and lexical features of regional dialects. It is certainly an oversimplification to assume that these school communities consist of monolinguals exclusively, but since Poland remains one of the most linguistically homogenous European countries (Wicherkiewicz 2014; see also section 5), we followed that oversimpli- 
fication during the selection of schools for the awareness-assessment phase in order to obtain a picture of the different needs of school communities from places where lesser-used and minority languages are spoken and those located in regions inhabited by the monolingual majority.

The enterprise described here was a public outreach and not a research project and no ethics approvals were sought. The goal of the awarenessassessment phase was to obtain general orientation in the form of the future educational material about endangered languages and the topics to be covered. During that phase, interviews with students were conducted with classrooms of approximately 25 and not with individuals in person, and the students' awareness of questions of language was assessed in general terms. The teachers had been informed beforehand about the objectives of the project and the teacher would announce to their students at the beginning of each lesson that they were going to participate in a special lesson in which they would be asked to assist linguists in developing school material about languages by providing feedback on which topics interest them the most.

The school visits had the form of semi-structured interviews conducted in classrooms during classes of school subjects whose teachers had volunteered to participate. The idea of a semi-structured interview had been shaped into a multimedia presentation containing interesting facts about languages (linguistic structures not found in the world's big languages, a video showing users of click languages speaking their language, etc.) and examples of different aspects of linguistic endangerment. Our interest was in hearing the students' impromptu responses to questions touching upon six thematic spheres and having them brainstorming ideas. Figure 1 presents the semi-structured interview sheet which served as basis for the presentation. The names of the six thematic concepts are given under 'concepts' and for each of them, a sample question is provided.

\begin{tabular}{|c|l|}
\hline NAME & \\
DATE & \\
SCHOOL & \\
CLASS & \\
\hline
\end{tabular}

\begin{tabular}{|c|c|c|c|}
\hline concept & awareness & focus & suggestions \\
\hline $\begin{array}{l}\text { Endangered languages ("What does it } \\
\text { mean that a language is endangered?") }\end{array}$ & & & \\
\hline $\begin{array}{c}\text { Linguistic endangerment (“What makes a } \\
\text { language endangered or safe?”) }\end{array}$ & & & \\
\hline $\begin{array}{l}\text { Location (“Where can endangered lan- } \\
\text { guages be found?") }\end{array}$ & & & \\
\hline $\begin{array}{c}\text { Identity ("What does it mean for the } \\
\text { speakers if their language becomes endan- } \\
\text { gered?") }\end{array}$ & & & \\
\hline
\end{tabular}


Investigationes Linguisticae, vol. XXXII

\begin{tabular}{|c|l|l|l|}
\hline $\begin{array}{c}\text { What happens (“What are the conse- } \\
\text { quences of languages dying out?”) }\end{array}$ & & & \\
\hline $\begin{array}{l}\text { Solutions (“What could be done to prevent } \\
\text { languages from becoming endangered?”) }\end{array}$ & & & \\
\hline
\end{tabular}

Figure 1: Semi-structured interview sheet.

The AMU team conducted the class, while the teachers sat in the classroom listening and observing; they had been invited to think of their own ideas which they would share with us during individual interviews following the presentation. The agenda for the lessons was to pose questions and have the students come up with their own answers and discuss whether their friends' answers (e.g. about the number of the world's languages) could be valid. Where the students showed increased interest in a particular thematic concept, additional questions were asked, whereas when we broached topics which they had few ideas about, we proceeded directly to presenting facts. At a certain point of the presentation, the precise theme of the future school materials was revealed and students were subsequently asked for ideas about ways to make the topic of endangered languages appealing to them and their peers in Poland and Europe. A member of the team recorded the lesson or, where there was no consent to record, wrote the students' ideas down onto the semi-structured interview sheet. The presentation would generally take up all the time at disposal (one to two 45-minute lessons).

Although it is not the purpose of this article to deliver a detailed discussion on the awareness of language endangerment among secondary school students, a short comment concerning the most interesting results of the interviews is definitely in place. Apart from the students in Wilamowice and Opole, who showed notably more awareness of questions such as multilingualism and the significance of language for the community of its speakers, the general tendency among the students interviewed was to understand language in terms of foreign languages one decides or is obliged to learn. Although they saw the link between language and identity, they were of the opinion that with the loss of the heritage language, one's identity can be changed, but not lost. Among the proposed measures to save endangered languages, the students mentioned e.g. relocating the speakers to warmer climates (an answer given in a classroom where the students had previously cited harsh living conditions which are due to cold climate as one of the reasons behind language endangerment). The thing that astonished virtually all the students was the range of linguistic diversity. Guesses about the number of living languages ranged from 30 to 1,500 and the most common answer was around 200, i.e. approximately the number of countries in the world. During the subsequent stages of product development, the linguistic diversity of the world emerged as the most promising and attractive leitmotiv for school lessons about endangered languages in Poland. An interesting observation is that Polish was not seen 
as an endangered language by the teenagers. This, I believe, might be in some respects surprising to linguists who are accustomed to the widespread beliefs of some groups of non-linguists about state languages being at risk because of e.g. the growing significance of English (see Milani 2007 for a discussion of Sweden).

\subsection{Creating materials}

Based on the feedback from students and teachers, we concluded that they happily accept the idea that endangered languages are introduced to schools - provided that school communities become informed about the topic. The picture of Polish secondary school students obtained during the interviews was that they differ not as much in awareness as in their actual interest in the topic. It became obvious that diversified material should be delivered which would both meet the expectations of students willing to explore the topic further on their own and leave a track in the minds of those who are and will remain uninterested after a lesson about endangered languages at school. The decision was made to split the product into parts and establish the http:/ languagesindanger.eu -website where the whole of it could be easily accessed by anybody interested. The product was divided into sections, e.g. a section labelled Teaching materials' was created to offer sets of lesson outlines and additional exercises, as well as support for the teachers willing to make use of them. This is the most vital part of the product in the sense that its content is meant to be used by teachers in schools, thus introducing students to the world of linguistic diversity and possibly providing impetus for more exploration. The activities offered by the remaining parts: 'Interactive map', 'Book of knowledge' and 'What you can do' are designed for those who wish to spend some of their free timelearning more.

The teachers interviewed after individual lessons enjoyed the presentation, but viewed the possible future use of materials about language endangerment in Polish secondary schools as limited. The advice given by teachers was to avoid creating any material which would not match curricula because of the scarcity of time for extra-curricular topics (see section 3 for more discussion). At the time the interviews were conducted, secondary school curricula were in a state of transition and new ones were going to be introduced starting from the school year 2012/ 2013. For this reason, any materials prepared before the new school year would have to be revised prior to its beginning. As it later turned out, the proper ministerial order (Order 2012) defining the content of the new school curricula only appeared on 27th August 2012, which put teachers under extreme pressure because the school year begins on $1^{\text {st }}$ September. The teachers admitted during the subsequent stages of collaboration that such situations are not exceptional, which only added to our concern about the working conditions in which Polish teachers function. 


\subsection{Testing and finalization}

While during the assessment phase linguists conducted lessons and teachers observed them, the testing stage involved an exchange of roles and handing over the task of introducing students to endangered languages to teachers. In Poland, only seven teachers participated in the testing phase, which is a much smaller number compared to the twenty two teachers who had taken part in the assessment stage. This is a telling result in its own right which will be elaborated on in section 3 , alongside some important pieces of feedback received from teachers during the testing phase.

The results of the testing of the material in Poland showed that multilingualism is too foreign a phenomenon for individual school lessons to effectively introduce teenagers to it. For example, one of the speaking exercises included in a lesson outline prepared for classes of English as a Foreign Language featured a question "Is it good or bad to have several languages in daily use on a given territory?". All the answers to that questions I heard during the exercise were against multilingualism as, in the view of the students, it hampered communication.

The finalization of the product involved first and foremost the rewriting of some lesson outlines according to the examination standards in Poland and other countries so as to enhance the prospects for obtaining recommendations of proper educational authorities and, as a result, for outlines being actually chosen by teachers in the future. Sections of the product other than 'Teaching materials' only required minor adjustments which were due to purposes of localization in the remaining countries.

\section{Goals versus reality: Time and money}

Grinevald (2007), Grenoble (2009) and others who discuss issues emerging where field linguists collaborate with communities of speakers of endangered languages point to the general problem that language professionals often present views on the documentation and revitalization enterprises they undertake which are at odds with those of the speech community. In the course of the public outreach project under the present report it turned out that the same is the case with external linguists wishing to spread the knowledge about endangered languages among school communities.

In recent years, an increasing number of field linguists have advocated community-based research over linguist-focused methods as the model of linguistic fieldwork preferred by speech communities (CzaykowskaHiggins 2009). This is not only for ethical reasons of responsibility to the community who are affected by the results of language documentation (Hale 2001, Rice 2010), but also because community involvement is indispensable for achieving the fundamental goals of language revitalization (Grenoble \& Whaley 2006, Grenoble 2009). Nevertheless, the underlying assumptions about the nature and objectives of linguistic fieldwork still 
differ among the groups of people involved in it. While linguists may treat the language under documentation as a system and an object of scientific inquiry, for community members language is inseparable from the traditional knowledge inherited from their ancestors and a vital ingredient of one's identity (Grenoble \& Whitecloud 2014). Even with convergent goals, perspectives may vary between academics and those for whom "fieldwork conditions" are the everyday reality and who are familiar with its practical aspects, which may lead to a critical underestimation of factors crucial for effective cooperation and ultimately, to the success of the enterprise. Consequently, linguists might be left struggling for the achievement of their goals. In this section I will present a couple of examples showing that very similar problems lurk ahead of linguists who launch public outreach projects.

\subsection{School system}

Already the onset of the series of school visits in the scope of INNET public outreach turned out to be the first point of clash between the academic and the school reality. There was a misunderstanding with the headmaster of one of the schools regarding the date of the visit and the school community was rather taken by surprise by the presence of AMU linguists. As a result, some rearrangements needed to be made ad hoc and the interview with students eventually took place during a class of a different school subject than originally planned. In the light of the fact that the school might lose their chance to participate in an EU-funded project, the teacher of that subject was asked to surrender her lesson. This resulted in tensions between the headmaster and the teacher, who received support from other teachers sharing the common feeling that they had been constantly being deprived of their classes because of the bulk of external activities the school was involved in, and feared that they would not manage to cover their subjects' curricula for that school year.

As it turned out later, the teacher belonged to those who normally show much willingness to take part in enterprises of this kind and was involved in a couple of projects herself. Unfortunately, she was unlucky to already have had $30 \%$ of all her lessons planned for the first semester cancelled only three months into the school year because of various noncurricular activities. After the main point of the visit had been covered, the teachers admitted during unofficial talks that this was an extremely problematic situation. That particular school consistently ranks among the top 100 secondary schools in Poland and is one of the best in the region. This is partially achieved through participation in school-external activities. The teachers are eager to become involved in them, but at the same time, face constant pressure placed on results in the regular course of teaching because what also counts in the rankings are the results of the school final examinations. All the teachers we talked to during that visit agreed that three years of secondary education practically mean two and a half years of scheduled classes because of the design of the final examination. In the- 
ory, the Polish school year lasts ten months from September to J une, but in grade three, when students sit their final examinations, they finish their school year in April, take exams in May and have J une off. Because the exams last for the whole of May and teachers of all school subjects are busy supervising them, Mays are the period when there is much shifting and class cancellation, and hardly any normal teaching takes place in secondary schools, also in grades one and two.

The teachers in other schools we visited later felt precisely the same way about how secondary education in Poland is organized: it is extremely focused on, if not totally subjected to final examinations, and good performance during the exams is practically the sole purpose of a student's existence in a secondary school. Most universities recruit first year students relying exclusively on the results of the final secondary school exams which, for this reason, are assigned an important role. The curricula are crammed and teachers end up running late completing them. Reportedly, this has been happening each year since the educational reform of 1999 when secondary education in Poland practically shrank by one year. School education in Poland lasts 12 to 13 years and is completed on the primary (six years), junior secondary (three years) and secondary level (three to four years). The tripartite division was introduced by the educational reform of 1999, which featured in a series of reforms affecting important domains of public life. The reforms were implemented by a rightwing government wanting to enhance the quality of everyday lives of Poles after several years of political instability which followed the collapse of communism. With a perspective of joining the European Union, the foundations of the educational reform were designed to acknowledge EU recommendations for creating equal educational opportunities and constantly upgrading the quality of teaching. This was meant to be achieved through a transformation of the old dichotomous division between primary and secondary education, lasting eight and four years respectively, into the abovementioned three-step path to adulthood, assisted by a system of external evaluation tests taken at the end of each of the stages. Taken altogether, the whole course of school education in Poland lasts twelve years but since 1999, secondary school communities are presented with a situation in which roughly the same volume of material as that of before the reform should be covered in considerably less time; junior secondary schools are an extension of primary rather than an introduction to secondary education.

The atmosphere during our visit to that particular school became quite nervous at one point, but eventually the school community was very happy with the participation and provided the team with useful feedback. Importantly, we learned our first lesson about how the very organization of the Polish school system influences the daily routine of secondary schools, which later proved to have important implications for the product. The future teaching materials would have to be designed so as fit into the topics covered during the final examinations as there is hardly any room for extra-curricular activities in Polish secondary schools. All sets of out- 
lines meant for school usage were necessarily supplemented by an information file stating explicitly which educational goals can be realized with the help of a particular outline because many teachers would need to make a quick decision on whether or not to spend time familiarizing themselves with the outline. At several points during the initial interviews and on later stages, time turned out to be of extreme importance. Due to the fact that teachers of several school subjects, e.g. Geography, have a limited number of hours in the weekly course of teaching, they would find it particularly difficult to cover extra-curricular topics. This translated to a need for introducing a fair degree of flexibility to the future teaching materials whereby not only whole outlines but also separate exercises could conveniently be used by teachers interested in making language endangerment the subject of the lesson.

Thus, the initial idea of linguists to create materials which would encourage young people to explore the fascinating world of languages had to be adapted to the point of view of an average Polish teacher who would most probably think in terms of whether the materials serve as means of fulfilling particular educational objectives, and how efficiently they do. However, more demanding than the creation of the initial version of the product was getting teachers involved in its testing.

\subsection{Teachers' working conditions}

The testing phase had been scheduled for spring 2013 and there was much flexibility as to possible dates when the product could be tested. Yet teachers showed strikingly little interest in participation, which left us with quite a concern since Polish teachers are commonly keen on certificates confirming their participation in school-external activities as they enhance their career prospects. We sought support in teacher training centres and contacted numerous secondary schools offering benefits in the form of certificates and packages with the final version of the product - with mysteriously no response. We were left with surprisingly many unanswered emails from teachers who had shown much enthusiasm during the assessment phase.

When asked about possible reasons behind it, two of the seven teachers who did get involved in the testing responded that from a teacher's point of view, it was not worth investing time and effort in testing materials which do not form integral parts of larger syllabus projects, e.g. textbooks or sets of final examination-like tests. The teachers also considered it possible that the unwillingness on the part of teacher training centres to help organize a workshop for teachers was due to the fact that unless courses offered are in cutting-edge teaching methods and use of modern technologies in teaching, centres rarely decide to host them as chances of attracting large groups of teachers are slim. Polish teachers are not too well-paid a professional group and to achieve higher levels in their careers, which also entail pay rises, teachers are supposed to participate in schoolings organized e.g. by teacher training centres. Courses often take place at 
weekends and if a teacher of a foreign language does not consider a particular schooling attractive in terms of their career prospects, they will mostly opt for additional earnings and run a weekend course at a private language school in the language they teach.

In Poland, 83\% of the population trust teachers, which makes them the seventh most trusted professional group, ahead of physicians or police officers (GfK Verein 2014: 29). In addition, teachers are assigned an important societal role, which may partly be an aftermath of the communist times: in the Soviet Union and Eastern European countries, education was of particular importance to the raising of new generations of socialist societies and strengthening their spirit (Grant 1975). Despite the establishment of a system of educational superintendence which theoretically was to support teachers in fulfilling their mission, teachers were oftentimes left with practically no assistance which would help them deal with the expectations they were faced with. The two teachers of English who participated in the testing phase held the view that many of their colleagues still find it shameful and difficult to admit to a lack of knowledge in front of their students. One of the teachers who had eagerly participated in the assessment phase and declared he would happily join the testing withdrew upon hearing that it was teachers and not linguists who were supposed to conduct lessons at that stage. Unfortunately, high expectations and the societal role that teachers play do not entail financial benefits which would provide the group with comfortable conditions for professional self-development.

The working conditions in which Polish secondary school teachers operate resemble the difficult situation of some groups of people with whom field linguists cooperate during documentation and revitalization projects. As emphasized by Grenoble \& Whaley (2006), the role of external linguists in language revitalization is to contribute as much as they can to the saving of an endangered language, but not to take over the responsibility for its fate. In a somewhat oversimplified situation, an endangered language is of value to Western linguists leading generously funded projects because of its structure or unique vocabulary, while the speakers of the language, whose living standards are substantially lower than those of scientists holding university positions, are more likely to expect long-lasting preservation of the culture of their ancestors, of which language is only one facet. As a result, activities connected with quick and effective documentation, which are a matter of utmost priority for many field linguists (Grinevald 2007), are easily perceived as external pressure which members of the community will likely resist.

I interpret the pressure exerted by outsiders to have considerably influenced the testing of the product in Polish secondary schools. Faced with multiple challenges posed by their work environment, teachers viewed their participation in the final stages of a pioneering EU-funded project as too much of a burden. Due to the relative novelty of the INNET project, it would have been overenthusiastic to expect grass-root movements led by school communities wishing to learn about endangered languages. Nevertheless, the consequences of the fact that it was linguists who set the tone 
were that the initial enthusiasm evaporated once teachers had started to perceive the whole undertaking as too demanding. It is essential to see the financial aspect of the problem: in a struggle for their economic well-being, teachers are often faced with a choice between familiarizing themselves with new educational materials and gaining immediate financial benefits. As a strategic group for linguists, especially in the Polish reality, teachers do not differ in this respect from members of endangered language communities in whose case linguists need to determine whether the group "are in a position to be engaged in language revitalization or spend time trying to provide food and shelter for themselves and their families" (Grenoble \& Whaley 2006: 44).

\section{Who needs training?}

Human resources, in the sense of people and their capacities, are part of the capital to be assessed in planning language revitalization projects (Grenoble \& Whaley 2006: 41). Grenoble (2009) notes that while many speech communities are extremely interested in having teaching materials which would furnish their language with a higher level of prestige and thus help revitalize it, linguists simply lack the pedagogical know-how necessary for the preparation of lesson outlines, textbooks and dictionaries:
"Linguists are specifically trained in elicitation and linguistic analysis. They are trained to take large amounts of linguistic data and make sense of it, to find the rules that govern how each language oper- ates. They are not, however, trained in language ped- agogy or the development of pedagogical materials, things which often interest communities above and beyond everything else." (Grenoble 2009: 64)

The help of people who possess such expertise is, therefore, of invaluable help to linguists. During the creation of a set of lesson outlines meant for classes of English as a Foreign Language (EFL), I had the precious opportunity of collaborating with an EFL teacher who is also an expert with one of the regional examination centres of Poland, trained in language testing methodologies and experienced in the legal regulations concerning suitability of school materials for the Polish educational market. The set was prepared based on her advice which was to include exercises testing all four skills (reading, listening, speaking and writing) and to apply proper levels of difficulty according to the type of material available. Here was where the principle of honest assessment of available resources became particularly important to the present enterprise, in a parallel fashion to language revitalization (cf. Grenoble \& Whaley 2006: 160). Unlike all other exercises in the EFL outline which contained prepared material, the interview used for two listening exercises was an example of authentic English, with moments of fast speech and the speaker's self-corrections. 
Studies show that having arrived at intermediate levels of foreign language learning, students generally enjoy authentic materials (e.g. Chavez 1998), although some sources report that they are viewed as more difficult than prepared ones (Richards 2001: 253). In order that failures and rejections of the interview-based exercises could be avoided during the testing phase, questions to these exercises were designed to be considerably simpler than those in the exercises following and preceding them. The testing of the outline showed that this was the right thing to do, but it also uncovered issues which I had not thought about when creating the outline.

During post-test interviews about the EFL outline, the two teachers who had tested it provided feedback which largely concentrated on the form of the outline rather than on its content. The teachers pointed out, for instance, that the material did not really conform to final examination standards in terms of task instruction, which was automatically putting it on a hiding to nothing on the educational market. The teachers recommended that the outline be rewritten to contain instructions in Polish and not in English, in accordance with how final examination sheets are prepared. There certainly is room for improvement in the training that linguists receive before they launch fieldwork or public outreach projects, but in the European context it is particularly important that apart from acquiring practical skills in preparing pedagogical materials, linguists grasp the importance of language testing as a general phenomenon and understand its influence on teaching. The language tester's impact goes far beyond the stage of actual test design (Shohamy 1993), which, in the particular case of EFL in Polish secondary schools, means that a fascinating new topic of endangered languages ultimately becomes pumped into the rigid form of outlines whose main objective is teaching to the test.

The EFL outline included an exercise whose target was to assess the student's linguistic prejudices. The exercise had been inspired by Hazen (2001) who recommends that the teacher measure the level of language intolerance' among their students by having them discuss statements such as "Some languages are better than others" prior to active learning. The task did not make the students very talkative during the lesson, so one of the teachers asked additional questions to stimulate discussion. Instead of bringing linguistic prejudices of the students to surface, the discussion around the first statement in that exercise uncovered the prejudices held by the teacher. With none of the students willing to present their view on whether "a language is something completely different from a dialect", the teacher started enumerating examples supportive of the claim that language is substantially different from a dialect, e.g. in that it exists in the written form.

Flores \& Smith (2009) show that irrespectively of their ethnic background and exposure to language diversity, teachers need training on the questions of language if they are to develop sensitivity to linguistic and cultural diversity of their classrooms. The results of the testing of the EFL outline in Poland suggest that where linguistic diversity is hardly a day-today occurrence, teachers' attitudinal beliefs about language require as 
close an observation as those of students because teachers may hold precisely the language attitudes that linguists want to challenge.

In the Polish context, teachers require particular attention and assistance from linguists because they play a pivotal role in educating students about endangered languages. But the experiences with product development in the remaining countries point to a conclusion that this is not necessarily the case everywhere.

\section{Each case is different}

The last parallel that I wish to draw between linguistic fieldwork and public outreach is that achieving the same goal - whether succeeding in the documentation of a dying language or awakening interest in endangered languages in monolingual teenagers - necessitates taking different measures at a local level.

In an article reporting on the development of teaching materials on language endangerment for secondary schools in the Netherlands, Odé (2008) notes the following:

"In the Netherlands and in many other countries, classrooms do not consist of students from one nationality, religion or race. In many Dutch schools, Dutch students are not even in the majority, and this part of the course tries to invoke awareness of this situation." (Odé 2008: 148)

In contrast, most Polish classrooms do consist of students representing one nationality, race, religion, and language. With its fifteen living autochthonous languages2: Belarusian, Czech, German, Karaim, Kashubian, Lemko, Lithuanian, Polish, Romani, Russian, Silesian, Slovak, Ukrainian, Wilamowicean and Yiddish, Poland makes a European average by linguistic diversity. However, the most recent census data available pictures it as an overwhelmingly monolingual country where Polish is the first language used at home for $94,5 \%$ of the population and the only language for $92,6 \%$ (Census 2011: 108).

Contrary to the Netherlands and other Western European countries, the linguistic environment of Poland has not experienced a fresh dose of multilingualism introduced by immigrants in recent decades and in most cases, familiarizing Polish school students with endangered lan-

2 The number equals the one given in the previously cited Lewis et al. (2014), but the catalogue of languages is different here. While being an invaluable reference for measuring linguistic diversity on a global scale, the successive versions of Ethnologue are as unreliable a source as others which attempt at providing precise numbers of languages used in different countries and list them by names. Lewis et al. (2014) mention e.g. Esperanto as one of the languages of Poland and separate Silesian from Upper Silesian. The list of languages employed in the present article is a subjective one, proposed by a Polish citizen and a linguist who personally assigns prominence to sociolinguistic criteria when discussing such questions. 
guages translates into introducing an entirely exotic topic. In Hungary, the situation is similar in terms of immigration, but attitudes to minorities are different. Prior to the testing, the Hungarian division of INNET introduced a series of changes to the outlines prepared in Poland, with the purpose of obtaining maximum local relevance of the topics covered. For Hungarian students, problems experienced by Hungarians living abroad turned out to be a sensitive topic and the situation of the Romani minority, which was the subject of one of the EFL outlines, fostered both interest and controversy. Such observations were not made in Poland where a lesson outline dealing with linguistic minority rights in Poland was met with univocal enthusiasm (Wójtowicz 2014) ${ }^{3}$.

That each local case is different is emphasized by experts in language revitalization:

"There is an understandable temptation when confronted with the monumental task of revitalization to look for that one single program which holds the key to success for different language groups around the globe, a tested framework that can be replicated for each situation. This simply does not exist, nor can it exist, because for every individual community a specific combination of issues enters into picture." (Grenoble \&Whaley 2006: 21)

The results of the INNET curriculum research (awareness-assessment phase) are particularly telling of the possibility that same is true for public outreach projects. Not surprisingly, endangered languages are not mentioned in school curricula as a separate topic, but in each of the four partner countries of INNET, i.e. Germany, Hungary, the Netherlands and Poland, the curricula for several secondary school subjects list educational goals which could be attained with the use of materials addressing different aspects of language endangerment. Table 1 summarizes the outcome of the curriculum research. The results for Germany are based on the official curriculum of the state of Nordrhein-Westfalen.

3 These results concern years 2011-2014. Intuitively speaking, things may be different now in 2015 just after the European migrant crisis, but I did not have access to studies revealing any possible changes in attitudes to ethnic minorities in Poland while finalizing this article. 
Table 1: School curricula in INNET partner countries and topics possibly related to language endangerment as of March 2012

(Wójtowicz et al. 2012).

\begin{tabular}{|c|c|c|c|c|}
\hline & Germany & $\begin{array}{l}\text { the Nether- } \\
\text { lands }\end{array}$ & Hungary & Poland \\
\hline $\begin{array}{c}\text { Duration of } \\
\text { education in } \\
\text { years (includ- } \\
\text { ing separate } \\
\text { secondary } \\
\text { education) }\end{array}$ & $12-13$ & $12-14(4-6)$ & 12 & $12-13(3-4)$ \\
\hline $\begin{array}{l}\text { School } \\
\text { subjects }\end{array}$ & $\begin{array}{l}\text { German lan- } \\
\text { guage; } \\
\text { Geography; } \\
\text { Social sciences }\end{array}$ & $\begin{array}{l}\text { Social science; } \\
\text { Geography; }\end{array}$ & $\begin{array}{l}\text { Man and soci- } \\
\text { ety; } \\
\text { Hungarian } \\
\text { language and } \\
\text { literature; } \\
\text { Foreign lan- } \\
\text { guages }\end{array}$ & $\begin{array}{l}\text { Polish language; } \\
\text { Foreign lan- } \\
\text { guage; Social } \\
\text { Studies; His- } \\
\text { tory; Cultural } \\
\text { Studies; Geog- } \\
\text { raphy; National } \\
\text { or ethnic minor- } \\
\text { ity language }\end{array}$ \\
\hline $\begin{array}{c}\text { Possibilities of } \\
\text { extra- } \\
\text { curricular } \\
\text { activities }\end{array}$ & $\begin{array}{l}\text { Individual pro- } \\
\text { jects in the } \\
\text { course of Ger- } \\
\text { man language at } \\
\text { the end of the } \\
\text { school year }\end{array}$ & $\begin{array}{l}\text { Room for extra- } \\
\text { curricular topics } \\
\text { in the course of } \\
\text { individual sub- } \\
\text { jects }\end{array}$ & $\begin{array}{l}\text { Project work } \\
\text { on topics of } \\
\text { particular } \\
\text { interest to } \\
\text { students }\end{array}$ & $\begin{array}{c}\text { School-external } \\
\text { activities }\end{array}$ \\
\hline
\end{tabular}

Effective introduction of topics connected with linguistic endangerment to Dutch schools may entail getting students involved in thematic projects, whereas in Poland it consists in creating lesson outlines which strictly comply with the final examination standards. Poland differs from other countries in an important respect: the school curriculum seemingly offers multiple ways of introducing topics related to language endangerment to schools because of the vast selection of school subjects, but due to the organization of the Polish school system and the extreme time pressure that it produces, the prospects for endangered languages becoming actually present in Polish schools are limited. Bridging the gap in knowledge and awareness of language endangerment between linguists and the general public with the use of school curricula basically means building bridges between linguists and young people, but at least in the Polish context, it is accurately assessing the role and addressing the needs of teachers who support these bridges that requires particular effort. In Germany, on the other hand, students can be accessed more directly by linguists because the teacher is not an indispensable link in the process of passing the knowledge about language endangerment. Instead, it is students themselves who can explore a new and fascinating topic of languages using e.g. online resources, and then present it to the rest of the classroom and the teacher at the end of the school year. 
While it is quite obvious that in different settings one will encounter different problems, grasping the idea that each situation is unique is a matter of adopting a certain perspective. As academic scholars, we might be intuitively tempted to seek generalizations and therefore select to develop a common educational product and to monitor the reception of its localized versions by school communities in different regions. This project has shown that it might not necessarily be the way to go. The AMU linguists had their work package with specific objectives and a timetable, but the Polish school reality made it very difficult to carry out these objectives in the scheduled time. The question for the future is, therefore, at which point the cooperation with school communities should really begin. The ultimate goal of a public outreach project is that the target school communities stay involved and ideally, also come up with bottom-up initiatives of their own. This, however, is unlikely to happen unless linguists make the creation of an environment for long-term relationships with local schools one of their top priorities. Similarly to linguistic fieldwork, then, public outreach enterprises are vulnerable to the risks posed by the so-called 'parachute linguist' approach (cf. e.g. Bradley 2007).

\section{Conclusion}

I should finally say it that contrary to the impression that the reader might have got from this article, I am far from deeming the public outreach project described here a failure. An interactive on-line resource has been developed as a result of INNET and individual teachers have already made further use of the lesson outlines offered by it, which meets the realistic minimal goal defined at the outset back in December 2011. My purpose in this paper has been to highlight one important fact that the project has revealed, a fact about what it means to introduce the topic of endangered languages to European schools. Namely that public outreach is much more than engaging in interaction with the general populace or creating attractive school materials about language endangerment. Equally, if not more important is the understanding of the broad socio-economic context in which such materials would be used, the needs and expectations of their potential users, and of the linguists' responsibility to the school communities. Thus, responsible cooperation with communities of non-linguists becomes a major objective in both linguistic fieldwork and in public outreach projects.

\section{References}

Admiraal, F. 2012. Elaborating teaching materials for Baure: When teachers are learners. Proceedings of the symposium on teaching and learning indigenous languages of Latin America. Kellogg Institute, University of Notre Dame. Retrieved from http:// kellogg.nd.edu/STLILLA/proceedings/Admiraal Femmy.pdf on $27^{\text {th }} \mathrm{J}$ anuary 2014. 
Amery, R., Buckskin, V. (J .) K. 2012. Handing on the teaching of Kaurna language to Kaurna youth. Australian Aboriginal Studies 30(2). 3141.

Bradley, D. 2007. What elicitation misses: Dominant languages, dominant semantics. Language Documentation and Description 4. 136- 144.

Census 2011 = Narodowy Spis Powszechny Ludności i Mieszkań 2011 [The National Population and Housing Census 2011]. Retrieved from

http://www.stat.gov.pl/cps/rde/ xbcr/gus/lud raport z wynikow NSP2 011.pdf on 13th J une 2014.

Chavez, M. M. Th. 1998. Learner's perspectives on authenticity. International Review of Applied Linguistic in Language Teaching 36. 277306.

Crystal, D. 2003, March. Crossing the great divide: Language endangerment and public awareness. Keynote speech to the International Expert Meeting on Endangered Languages, UNESCO, Paris.

Crystal, D. 2011. Language diversity, endangerment, and public awareness. British Academy Review 18. 12- 20.

Czaykowska-Higgins, E. 2009. Research models, community engagement, and linguistic fieldwork: Reflections on working within Canadian Indigenous communities. Language Documentation \& Conservation 3. $15-50$.

Dorian, N. C. 1998. Western language ideologies and small-language prospects. In Lenore A. Grenoble and Lindsay J. Whaley (eds.), Endangered languages: Current issues and future prospects. 3-21. Cambridge: Cambridge University Press.

Flores, B. B., Smith, H. L. 2009. Teachers' characteristics and attitudinal beliefs about linguistic and cultural diversity. Bilingual Research J ournal 3. 323- 358.

GfK Verein. 2014. Trust in professions. Retrieved from www.gfk.com/ Doc uments/Press-Releases/2014/GfK Trust\%20in\%20Professions e.pdf on $8^{\text {th }}$ March 2015.

Gippert, J., Himmelmann, N., Mosel, U. (eds). 2006. Essentials of language documentation. Berlin: Mouton de Gruyter.

Grant, N. 1975. Teacher education in the USSR and Eastern Europe. British J ournal of Teacher Education 1. 383- 400.

Grenoble, L. A. 2009. Linguistic cages and the limits of linguists. In J on Reyhner and Louise Lockard (eds.), Indigenous language revitalization: Encouragement, guidance \& lessons learned. 61-69. Flagstaff: Northern Arizona University.

Grenoble, L. A., Whaley, L. J . 2006. Saving languages: An introduction to language revitalization. New York: Cambridge University Press.

Grenoble, L. A., Whitecloud, S. S. 2014. Conflicting goals, ideologies and beliefs in the field. In J ulia Sallabank and Peter K. Austin (eds.), Endangered languages: Beliefs and ideologies in language documentation and revitalisation. 337- 354. Oxford: Oxford University Press.

Grinevald, C. 2007. Linguistic fieldwork among speakers of endangered languages. In Osahit oMiyaoka, Osamu Sakiyama and Michael E. 
Krauss (eds.), The vanishing languages of the Pacific Rim. 35- 76. Oxford: Oxford University Press.

Hale, K. 2001. Ulwa (Southern Sumu): The beginnings of a language research project. In Paul Newman and Martha Ratliff (eds), Linguistic fieldwork. 76- 101. Cambridge: Cambridge University Press.

Hazen, K. 2001. Teaching about dialects. Washington, DC: Eric Clearinghouse on Languages and Linguistics.

Himmelmann, Nikolaus. 1998. Documentary and descriptive linguistics. Linguistics 36. 161- 195.

Hornberger, N. H., King, K. A., 2001. Reversing Quechua language shift in South America. In J oshua Fishman (ed.), Can threatened languages be saved? Reversing language shift, revisited: A 21st century perspective. 166- 194. Clevedon: Multilingual Matters.

Lewis, M. P., Simons, G. F., Fennig, C. D. (eds.). 2014. Ethnologue: Languages of the world, Seventeenth edition. Dallas: SIL International.

Milani, T. M. 2007. Voices of endangerment: A language ideological debate on the Swedish language. In Alexandre Duchêne and Monica Heller (eds.), Discourses of endangerment: Ideology and interest in the defence of languages. 169- 196. London: Continuum.

Nettle, D., Romaine, S. 2000. Vanishing voices: The extinction of the world's languages. Oxford: Oxford University Press.

Odé, C. 2008. Teaching materials on language endangerment. An interactive e-learning module on the Internet. In Tjerd de Graaf, Nicholas Ostler, and Reiner Salverda (eds.), Endangered languages and language learning: Proceedings of the conference FEL XII: 24- 27 September 2008, Ljouwert/ Leeuwarden. 147-150. Leeuwarden: FryskeAkademy.

Order 2012 = Rozporządzenie Ministra Edukacji Narodowej z dnia 27. sierpnia 2012 r. w sprawie podstawy programowej wychowania przedszkolnego oraz kształcenia ogólnego w poszczególnych typach szkół [The Order of the Minister of National Education of 27th August 2012 on preschool and general education curricula in individual school types]. Dziennik Ustaw Rzeczypospolitej Polskiej, poz. 977. Retrieved from http:/ / isap.sejm.gov.pl on 27th J anuary 2014.

Richards, J. C. 2001. Curriculum development in language teaching. Cambridge: Cambridge University Press.

Rice, K. 2010. The linguist's responsibilities to the community of speakers: Community-based research. In Lenore A. Grenoble and N. Louanna Furbee (eds), Language documentation: Practice and values. 25- 36. Amsterdam: J ohn Benjamins.

Shohamy, E. 1993. The power of tests: The impact of language tests on teaching and learning. Washington, DC: The National Foreign Language Center at J ohn Hopkins University.

Slaughter, H. B. 1997. Indigenous language immersion in Hawaii. In Robert K. J ohnson and Merrill Swain (eds), Immersion education: International perspectives. 105-130. New York: Cambridge University Press. 
Radosław Wójtowicz: Endangered languages in public outreach

Wicherkiewicz, T. 2014. Minority language education in Poland and the European Charter for Regional or Minority Languages. In Magdalena Olpińska and Loretta Bertelle (eds.), Zweisprachigkeit und Bilingualer Unterricht. 151- 178. Frankfurt am Main: Peter Lang.

Wójtowicz, R. 2014. Language endangerment in European secondary schools: Challenges and perspectives. In Elisabetta Delle Donne et al. (eds), The Future of Education, $4^{\text {th }}$ edition: Conference proceedings. 236- 240. Padova: Libraria Universitaria.

Wójtowicz, R., Linda, K., Nau, N., Wicherkiewicz, T., Hornsby, M., Duray, Z., Trilsbeek, P., J ung, D. 2012. INNET Awareness report. Retrieved from http://innet-project.eu/sites/default/files/D4.1_ Awareness.pdf on $13^{\text {th }} \mathrm{J}$ une 2014. 